\title{
Deficiency and toxicity of nanomolar copper in low irradiance-A physiological and metalloproteomic study in the aquatic plant Ceratophyllum demersum
}

\author{
George Thomas a ${ }^{\text {, Elisa Andresen }}{ }^{\mathrm{a}, \mathrm{b}}$, Jürgen Mattusch ${ }^{\mathrm{c}}$, Tomáš Hubáček ${ }^{\mathrm{d}, \mathrm{e}}$, \\ Hendrik Küpper ${ }^{a, b, f, *}$ \\ a University of Konstanz, Department of Biology, D-78457 Konstanz, Germany \\ ${ }^{\mathrm{b}}$ Institute of Plant Molecular Biology, Department Plant Biophysics and Biochemistry, Biology Centre of the ASCR, Branišovská 31/1160, CZ-37005 České \\ Budějovice, Czech Republic \\ ' UFZ - Helmholtz Centre for Environmental Research, Department of Analytical Chemistry, Permoserstr. 15, D-04318 Leipzig, Germany \\ d Institute of Hydrobiology, Department of Hydrochemistry and Ecosystem Modelling, Biology Centre of the ASCR, Na Sádkách 7, 37005 České Budějovice, \\ Czech Republic \\ e SoWa National Research Infrastructure, Biology Centre of the ASCR, Na Sádkách 7, 37005 České Budějovice, Czech Republic \\ f University of South Bohemia, Faculty of Biological Science, Branišovská 31/1160, CZ-37005 České Budějovice, Czech Republic
}

Keywords:

Ceratophyllum demersum

Biophysics of photosynthesis

Chlorophyll fluorescence kinetics

Copper deficiency

Physiological stress

Metalloproteomics

\begin{abstract}
A B S T R A C T
Essential trace elements $\left(\mathrm{Cu}^{2+}, \mathrm{Zn}^{2+}\right.$, etc) lead to toxic effects above a certain threshold, which is a major environmental problem in many areas of the world. Here, environmentally relevant sub-micromolar concentrations of $\mathrm{Cu}^{2+}$ and simulations of natural light and temperature cycles were applied to the aquatic macrophyte Ceratophyllum demersum a s model for plant shoots. In this low irradiance study resembling non-summer conditions, growth was optimal in the range 7.5-35 nM Cu, while PSII activity $\left(\mathrm{F}_{\mathrm{v}} / \mathrm{F}_{\mathrm{m}}\right)$ was maximal around $7.5 \mathrm{nM} \mathrm{Cu}$. Damage to the light harvesting complex of photosystem II (LHCII) was the first target of $\mathrm{Cu}$ toxicity ( $>50 \mathrm{nM} \mathrm{Cu}$ ) where $\mathrm{Cu}$ replaced $\mathrm{Mg}$ in the LHCII-trimers. This was associated with a subsequent decrease of Chl a as well as heat dissipation (NPQ). The growth rate was decreased from the first week of Cu deficiency. Plastocyanin malfunction due to the lack of $\mathrm{Cu}$ that is needed for its active centre was the likely cause of diminished electron flow through PSII ( $\left.\Phi_{\text {PSII }}\right)$. The pigment decrease added to the damage in the photosynthetic light reactions. These mechanisms ultimately resulted in decrease of starch and oxygen production.
\end{abstract}

\section{Introduction}

Copper is an essential plant micronutrient which belongs to the $3 \mathrm{~d}$ transition elements along with iron, zinc, etc. In living cells, divalent copper $\left(\mathrm{Cu}^{2+}\right)$ is readily reduced to monovalent $\left(\mathrm{Cu}^{+}\right)$copper, which is unstable and gets oxidized back unless it is stabilised by strong ligands (e.g. metallothioneins in the cytoplasm). Most of the physiological processes of plants including photosynthesis, respiration, carbohydrate distribution, nitrogen reduction and fixation, protein metabolism, and cell wall metabolism (Sommer, 1931; Lipman and McKinney, 1931) are based on the participation of the

* Corresponding author at: Institute of Plant Molecular Biology, Department Plant Biophysics and Biochemistry, Biology Centre of the ASCR, Branišovska 31/1160, CZ37005 Česke Budějovice, Czech Republic.

E-mail address: Hendrik.Kuepper@umbr.cas.cz (H. Küpper). enzymatically bound copper in the redox reactions (Marschner, 1995). In biological systems, $\mathrm{Cu}$ is either $\mathrm{Cu}^{2+}$ or $\mathrm{Cu}^{+}$, but in the following text we usually do not display redox states, as we did not determine the redox states of any metals in this study.

Three different forms of proteins exist in which copper is the metal component as summarized by Sandmann and Böger (1983) namely (1) blue proteins without oxidase (e.g. plastocyanin), functioning in one electron transfer; (2) non blue proteins, which includes peroxidases and oxidases; (3) multicopper proteins with at least 4 copper atoms per molecule that act as oxidase (e.g. ascorbate oxidase and diphenol oxidase). During Cu deficiency or when there is removal of $\mathrm{Cu}$ from these enzymes, they become inactivated (Vallee and Wacker, 1970).

Despite being essential, copper has a particularly narrow beneficial range and becomes easily toxic to organisms. Thus, the most important practical implications of the role of copper in plants are related to its deficiency and toxicity (Kabata-Pendias and Pendias, 
1984). In natural waters, the concentration of $\mathrm{Cu}$ is less than $30 \mathrm{nM}$ (Baccini, 1985), but anthropogenic activity (industrial and municipal waste waters, fertilizers, especially in wine yards) can yield concentrations up to $30 \mu \mathrm{M}$ in polluted areas (Yamamoto et al., 1985; Zhang et al., 2003). One major metal toxicity mechanism in photosynthetic organisms is the damage of the photosynthetic electron transport chain (reviewed by Küpper and Kroneck, 2005). The substitution of $\mathrm{Mg}^{2+}$ in the chlorophyll (Chl) molecule by heavy metal ions leads to the formation of a heavy metal substituted chlorophylls, [hms]-Chls (Küpper et al., 1996, 2002). Those [hms]Chls are unsuitable for photosynthesis for several reasons (Küpper et al., 2006): Compared to [Mg]-Chl, the singlet excited state is very short-lived, S1 relaxes to the S0 state before the exciton can be transferred. This is especially detrimental when [Cu]-Chl is located in the reaction centre of photosystem II (PSIIRC). Under high light conditions, [Cu]-Chl forms predominantly in the Phe a of the PSIIRC, making the whole photosystem functionless. In green algae and higher plants (Chlorophyta), formation of [Cu]-Chl in the Chls of the antennae is more likely to happen under low light conditions. Those $[\mathrm{Cu}]$-Chls do not transfer captured photons as excitons to the other $\mathrm{Chl}$ molecules, but just release the energy as heat. Therefore, even a small number of $\mathrm{Cu}$-substituted Chls within the antenna complex means that the whole photosystem is lost for the plant. The light environment is an important factor for the mode of $\mathrm{Cu}$ (and other toxic metals) toxicity, as it changes the position of [Cu]-Chl formation. Another reason for the unsuitability of [hms]-Chls is a lower tendency to bind axial ligands (Küpper et al., 2006), which changes the conformation of the antenna molecules and leads to diminished or inhibited exciton transport. Generally, any disturbance in the photosynthetic or respiratory electron transport chain is known to enhance the formation of reactive oxygen species, when electrons are transferred to oxygen instead of their proper acceptor (Asada 2006; Pospíšil 2012).

On the other side, insufficient $\mathrm{Cu}$ nutrition is detrimental to the plants as well: Symptoms of Cu deficiency including decreased growth rate, chlorosis of young leaves, curling of leaf margins and decrease in fruit formation were observed in plants when $\mathrm{Cu}$ decreased below $5 \mu \mathrm{g} \mathrm{g}^{-1} \mathrm{DW}$ in the vegetative tissue (Marschner, 1995). This led to decrease in the pigments (chlorophyll and carotenoids), damage to the chloroplast's thylakoid membranes (Droppa et al., 1987), reduced plastoquinone synthesis, depressed $\mathrm{CO}_{2}$ fixation (Bussler 1981) and decreased PSII activity (Thomas et al., 2013). The damage to the photosynthetic apparatus will divert absorbed light energy towards different processes, finally resulting in oxidative stress. Due to the decrease in $\mathrm{Cu}$ availability, there is no proper functioning of the $\mathrm{Cu} / \mathrm{Zn}-\mathrm{SOD}$, causing further rise of oxidative stress (Marschner, 1995; Küpper and Kroneck, 2005).

Most earlier experiments have used $\mathrm{Cu}$ concentrations much higher than environmentally relevant (from $1 \mu \mathrm{M}$ to more than $240 \mu \mathrm{M}$; Palms et al., 1990) to show immediate response on physiology and protein biosynthesis with the time duration of the growth study between $10 \mathrm{~h}$ (Delhaize et al., 1985) to $13 \mathrm{~d}$ (Delhaize et al., 1986).

We used the model plant Ceratophyllum demersum L., which is an aquatic submerged macrophyte. It has no roots, all nutrients are taken up over a large surface area of the entire shoot and it is sensitive to metal stress (Küpper et al., 1996, 1998; Mishra et al., 2008, 2009, 2013, 2014; Andresen et al., 2013a,b, 2016; Thomas et al., 2013). Our previous study (Thomas et al., 2013) analysed the effects of Cu deficiency and toxicity under high light conditions, like what C. demersum experiences in summer (Andresen et al., 2013b). This study was conducted under low light conditions to analyse the biochemical and biophysical responses to $\mathrm{Cu}$ stress in the remainder of the year.

\section{Material and methods}

\subsection{Plant material and cultivation}

Ceratophyllum demersum L. (the submerged, rootless macrophyte) was cultivated in an optimized nutrient solution for submerged macrophytes and water plants (SMNS, submerged macrophyte nutrient solution as used in our previous recent studies: Andresen et al., 2013a,b, 2016; Mishra et al., 2013, 2014; Thomas et al., 2013). The strain has been continuously cultivated since 2005 in hydroponic cultures under $12 \mathrm{~h}$ day/12 h night light conditions with two Osram FLUORA ${ }^{\circledR}$ fluorescent and two warm white fluorescent tubes and a temperature cycle from $18^{\circ} \mathrm{C}$ at 6 a.m., over $20^{\circ} \mathrm{C}$ at 9 a.m., to a maximum of $22^{\circ} \mathrm{C}$ at 3 p.m., back over $20^{\circ} \mathrm{C}$ at 9 p.m. to $18^{\circ} \mathrm{C}$ again at 6 a.m. During the low light experiment a slightly different setup with light intensity to depict winter conditions ( $12 \mathrm{~h}$ sinusoidal light cycle with maximal irradiances at $38-40 \mu \mathrm{E}$ inside the aquaria and $12 \mathrm{~h}$ night $)$ and temperature $\left(19^{\circ} \mathrm{C}\right.$ at 6 a.m., 21.5 at 9 a.m., 24 at 3 p.m., 23 at 9 p.m., 19 at 6 a.m.) conditions were provided.

Eleven different copper concentrations, “0”, 0.5, 1, 2, 5, 10, 20, 50, $100,200,500 \mathrm{nM}$ in SMNS, were prepared with $\mathrm{CuSO}_{4}$. The " 0 " treatment had, despite a lot of effort (ultra-pure chemicals, acid-wash of all aquaria, tubes and glassware that were used to handle the plants, filtration of air supplied to the aquaria etc.), a background level of approx. $0.1 \mathrm{nM} \mathrm{Cu}$ in the barrels (see Thomas et al., 2013; Suppl. data). For each copper treatment, around $2 \mathrm{~g}$ of plants were placed into an aquarium containing 21 of continuously aerated medium to secure a low biomass to water volume ratio. The nutrient solution was exchanged continuously (flow rate $0.51 . \mathrm{day}^{-1}$ ) to ensure that the metal uptake into the plants was limited only by the concentration, and not by the amount of nutrient solution available. Each of the four experiments was carried out for 6 weeks and photosynthesis parameters (see below) and growth were determined weekly. After each week the aquaria and plants were cleaned (epiphytic algae and cyanobacteria removed) and the change in growth was measured after shaking off the remaining SMNS. After the 6 weeks of exposure to $\mathrm{Cu}$, the plants were harvested (removing the SMNS by shaking) and separated into young tissues, $4 \mathrm{~cm}$ from the apex and $2 \mathrm{~cm}$ from the apex of each side branch, and old tissues, $8 \mathrm{~cm}$ from the stem end and the rest of the side branches. Samples were immediately frozen in liquid nitrogen and stored at $-80^{\circ} \mathrm{C}$ until further analyses.

\subsection{Photosynthesis biophysics}

Two-dimensional (imaging) microscopic measurements using the Chl fluorescence kinetic microscope (Küpper et al., 2007a) were performed to study the physiological changes in the plant in response to copper stress. One leaf from the 5th nodium, counted from the apex of the plant, from each week of treatment, was fixed in the measuring chamber with the help of cellophane. There was a continuous flow of the culture medium in the chamber (Küpper et al., 2008) that was used for the kinetics measurement. An area (approximate size of $1.1 \times 1.1 \mathrm{~mm}$ ) just before the last leaf branching point was measured. A detailed description of the microscope, the used protocols and analysed parameters of the Kautsky induction can be found in Küpper et al. (2007a).

\subsection{Oxygen exchange}

Before the $\mathrm{Cu}$ treatments and after six weeks of $\mathrm{Cu}$ treatments, all the plants of one aquarium (1-3 plants) were placed into a $200 \mathrm{ml}$ measuring chamber (custom made), maintained at $25^{\circ} \mathrm{C}$ and oxygen exchange was measured by a WTW CellOx 325 oxygen electrode connected to an inoLab Oxi 740 termi- 
nal (Wissenschaftlich-Technische Werkstätten GmbH, Weilheim, Germany). Oxygen uptake in the dark and photosynthetic oxygen release was measured by exposing the plant to increasing irradiance. At the end, respiratory oxygen uptake in darkness was measured again. Data were recorded using the OxyCorder device with the software Oxywin 2.71 (Photon Systems Instruments, Brno, Czech Republic) and further data analysis was done in Origin Professional (versions 8.1-2015, Originlab, Northampton, USA).

\subsection{Determination of pigment content}

Pigments were extracted from the harvested plant material. The pigment extraction and determination were performed using established protocols by Küpper et al. (2007b) as described in Thomas et al. (2013). Briefly, samples were lyophilized and subsequently ground with sand and a few grains of Bis-Tris (SigmaAldrich, St Louis, MO, USA). Extraction of pigments was performed in $1 \mathrm{ml} 100 \%$ acetone at $4{ }^{\circ} \mathrm{C}$ overnight. Pigment quantification was performed by the Gauss Peak Spectra (GPS) method of Küpper et al. (2007b).

\subsection{Starch quantification}

The amount of accumulated starch in the harvested plant samples after 6 weeks of treatment was analysed using the Total starch assay kit (AOAC Method 996.11 and AACC Method 76.13; Megazyme, Wicklow, Ireland) downscaled for our demands (Mishra et al., 2014; Thomas et al., 2013).

\subsection{Elemental analyses of digested plant samples}

Following the protocol of Zhao et al. (1994), 5-10 mg of lyophilised plant samples were digested in $250 \mu \mathrm{l}$ nitric-perchloric acid mix (85\%:15\%) for $30 \mathrm{~min}$ at room temperature and then gradually heated up to a maximum of $195^{\circ} \mathrm{C}$ until all liquid was vaporized. The remaining salts were re-dissolved in $0.5 \mathrm{ml} 5 \% \mathrm{HCl}$ and gradually heated to $80^{\circ} \mathrm{C}$. The samples were allowed to cool and then the volume was filled to $1.5 \mathrm{ml}$ with $\mathrm{ddH}_{2} \mathrm{O}$ and used for analyzing the elemental composition using the graphite furnace atomic absorption spectrometer (GF-AAS) GBC923AA with the furnace GF3000 and autosampler PAL 3000 (GBC Scientific Equipment Pty Ltd, Breaside Vic., Australia).

\subsection{Isolation of proteins}

For isolation of protein, $400 \mathrm{mg}$ of frozen harvested plants were ground to fine powder in a mortar cooled with liquid nitrogen. Isolation buffer (IB: $750 \mathrm{mM}$ aminocaproic acid, $50 \mathrm{mM}$ Bis-Tris (Sigma-Aldrich), pH 7.6, suprapure $\mathrm{HCl}$ (Roth), $2 \%$ $360 \mathrm{kDa}$ polyvinylpyrrolidone (PVP; Sigma-Aldrich) and $1.2 \mathrm{mg} / \mathrm{mL}$ 'complete' EDTA-free protease inhibitor cocktail tablets (Roche Diagnostics, Mannheim, Germany) was also frozen by letting droplets fall into liquid nitrogen, and then ground with the plant material in $1: 1(\mathrm{w} / \mathrm{v})$ ratio. The powdered mixture was placed on ice for thawing. Afterwards, the suspension was mixed with another $400 \mu \mathrm{l}$ of IB and transferred into a $1.7 \mathrm{ml}$ ultracentrifuge tube (Beckmann, Palo Alto, CA, USA) and centrifuged for $1 \mathrm{~h}$ at $134,000 \mathrm{~g}$ at $4{ }^{\circ} \mathrm{C}$ in a Beckman LE $80 \mathrm{~K}$ preparative ultracentrifuge (Beckmann, Palo Alto, CA, USA). The supernatant was centrifuged immediately again for $10-60 \mathrm{~min}$ at $16,000 \mathrm{~g}, 1^{\circ} \mathrm{C}$ in a microcentrifuge (Centrifuge 5415R, Eppendorf AG, Hamburg, Germany) to remove re-suspended pieces of pellets; afterwards it was used for the soluble protein analysis. The pellet from the ultracentrifugation was washed twice with IB and the supernatant was discarded after centrifugation. The pellet was mixed with solubilisation buffer (SB: $750 \mathrm{mM}$ aminocaproic acid, $50 \mathrm{mM}$ Bis-Tris, pH 7.0 with $\mathrm{HCl}$ at $1-2{ }^{\circ} \mathrm{C}$ - neutral to avoid allomerisation and saponification of Chl, 2\% n-Dodecyl $\beta$-D-maltoside (DDM; Affymetrix Inc., Maumee, $\mathrm{OH}, \mathrm{USA}$ ), $1.2 \mathrm{mg} / \mathrm{mL}$ 'complete') and stirred overnight at $4{ }^{\circ} \mathrm{C}$. The supernatant, after centrifuging it twice as mentioned above, was used for the analysis of the membrane proteins. The protein samples were stored on ice in the dark.

\subsection{Metalloproteomics}

For size exclusion chromatography of the soluble proteins, two Superose 12 10/300 GL columns (GE Healthcare) coupled in series in an Agilent 1100 series HPLC system (Agilent, Santa Clara, California, USA) equipped with two detectors: (1)UV/VIS absorption diode array detector (G1315B), (2) inductively coupled plasma mass spectrometer (Agilent 7500ce ICP-MS). Integration times for ICPMS were ${ }^{24} \mathrm{Mg} 0.1 \mathrm{~s},{ }^{59} \mathrm{Co} 0.1 \mathrm{~s} ;{ }^{63} \mathrm{Cu} 0.6 \mathrm{~s},{ }^{66} \mathrm{Zn} 0.6,{ }^{111} \mathrm{Cd} 0.6 \mathrm{~s}$. Molecular weights were calibrated with standard 151-1901 from BioRad (Hercules, California, USA), dissolved in water. The concentration of the standard injected into the chromatography column contained $0.5 \mathrm{mg} \mathrm{ml}^{-1}$ each of bovine thyroglobulin $(670 \mathrm{kDa})$, bovine $\gamma$ globulin (158 kDa), chicken ovalbumin (44 kDa), and $0.25 \mathrm{mg} \mathrm{ml}^{-1}$ horse myoglobin (17 kDa), as well as $0.05 \mathrm{mgml}^{-1}$ vitamin B12 (1.35 $\mathrm{kDa}$ ). Vitamin B12 (cobalamin) was added to all samples as an internal standard for calibration of the columns. The samples were filtered through a $0.2 \mu \mathrm{m}$ membrane filter and $40 \mu \mathrm{L}$ of sample (equiv. to $20 \mathrm{mg}$ fresh biomass) containing $0.01 \mathrm{mg} \mathrm{ml}^{-1}$ vitamin B12 was injected into the column. All samples were eluted with $150 \mathrm{mM}$ ammonium hydrogen carbonate (LC-MS grade, SigmaAldrich, USA).

The size exclusion chromatography of membrane proteins was very similar, but carried out on a different HPLC system, as described in Andresen et al., 2016.

For all samples, the ICPMS count rates and the protein absorbances ( $280 \mathrm{~nm}$ and $597 \mathrm{~nm}$ ) were normalized to the signal intensities of $\mathrm{Mg}$, as this was rather constant in the plants. Besides $\mathrm{Cu}, \mathrm{Zn}$ was measured for detection of the SOD standard, Mg was measured for detection of the $\mathrm{Mg}$-Chl peaks.

\subsection{Statistics}

One-way and two-way analysis of variance (ANOVA) was done in SigmaPlot 12 (Systat Software Inc., San Jose, CA, USA) at the significance level of $\mathrm{P}<0.05$ with $\mathrm{Cu}$ concentration and weeks of exposure to $\mathrm{Cu}$ stress as independent variables for the weekly measured data and $\mathrm{Cu}$ concentration and age as independent variables for the data obtained from the harvested material. In case of significant effects, the Holm-Sidak method was used for an all-pairwise post-hoc multiple comparison. Within the programme, data were tested for normality.

\section{Results}

From the whole range of parameters analysed on the response of the plants to copper, from deficiency via optimal to toxic concentrations, it was possible to establish the threshold concentrations and time sequence of events leading to optimal or suboptimal growth in low light. To reduce noise, which generally was a problem for detection of the sometimes small sublethal effects, the measured data were averaged as pairs (" 0 " $n M+0.5 n M, 1 n M+2 n M, 5 n M+10 n M$, $20 \mathrm{nM}+50 \mathrm{nM}, 100 \mathrm{nM}+200 \mathrm{nM}, 500 \mathrm{nM})$, resulting in 6 different analysed $\mathrm{Cu}$ concentrations.

\subsection{Visible symptoms and growth}

The plants looked healthy with green leaves and strong meristems with maximum growth rate in range between $7.5-35 \mathrm{nM} \mathrm{Cu}$ 


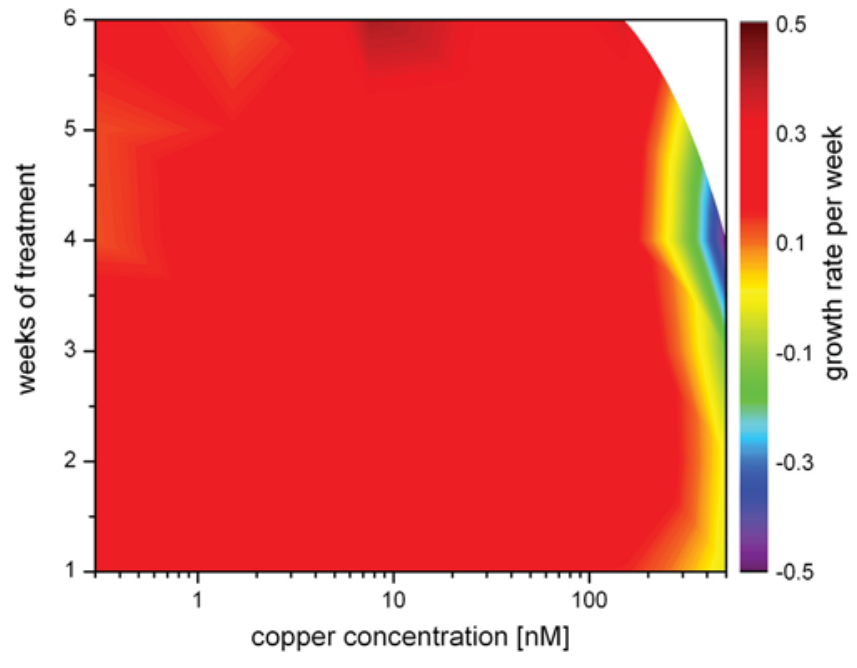

Fig. 1. Effect of $\mathrm{Cu}$ on the growth of Ceratophyllum demersum. Growth rates of the plants per week were calculated on the basis of fresh weight. Values are given as means of four different experiments.

especially towards the sixth week of treatment (Fig. 1; degree of freedom $=\mathrm{DF}=5$ for $\mathrm{Cu}$ concentration, 6 for weeks of exposure). No visible symptoms of toxicity were observed at the higher concentrations, but the growth rate did not reach a maximum when compared to control ( $10 \mathrm{nM} \mathrm{Cu}$ as used in stock cultures) at any point of time. Toxicity symptoms were severe at $500 \mathrm{nM} \mathrm{Cu}$ where negative growth rate (=shrinking of the plant) and loss of leaves from the stem, and decrease in chlorophyll contents had been reported (Fig. 1). These plants stopped growth immediately after treatment start and died after the fourth week of exposure to $500 \mathrm{nM} \mathrm{Cu}$. Only this treatment yielded effects that were statistically different from all others $(P \leq 0.001)$. Deficiency was registered with a subsequent reduction in growth rate from the first week on. The growth rate of the $0.3 \mathrm{nM}$ plants decreased from $0.25 \mathrm{~g}$ to $0.17 \mathrm{~g}$. However, no shrinking occurred in the deficient plants throughout the experiment. The deficiency symptoms such as decrease of leaf size, fragile stem, loss of leaves from the bottom of the stem were registered only in the " 0 " nM Cu after six weeks of treatment, showing that the plants still could utilize stored $\mathrm{Cu}$ for many weeks.

\subsection{Photosynthetic parameters by FKM}

Changes in photosynthetic light reactions were identified using the fluorescence kinetic analysis. Copper treatment influenced the maximum fluorescence in dark adapted state $\left(\mathrm{F}_{\mathrm{m}}\right)$ more towards the toxic than the deficient concentrations (Fig. 2; DF=5 for $\mathrm{Cu}$ concentration, 6 for weeks). The parameter $F_{v} / F_{m}$, which measures the photosynthetic quantum efficiency of PSII RC in dark adapted state, decreased towards the higher $\mathrm{Cu}$ concentrations from the fourth week. All treatments were significantly different from the second highest one $(150 \mathrm{nM} \mathrm{Cu}, \mathrm{P} \leq 0.001)$.

The photochemical activity of PSII in actinic light, which is related to the electron flow through PSII ( $\Phi_{\mathrm{PSII}} \mathrm{i} 1$ and $\Phi_{\mathrm{PSII}} \mathrm{i} 6$, also called "photochemical quenching" (Genty et al., 1989)), generally was optimal around $10 \mathrm{nM} \mathrm{Cu}(7.5 \mathrm{nM}-35 \mathrm{nM}$; Fig. 3). Differences due to $\mathrm{Cu}$ treatment and exposure duration were observed $(\mathrm{DF}=5$ for $\mathrm{Cu}, 6$ for weeks) for all $\Phi_{\text {PSII }}$ and NPQ parameters. The electron flow through PSII was diminished in deficiency $(0.3 \mathrm{nM}-1.5 \mathrm{nM})$ and toxicity $(150 \mathrm{nM}-500 \mathrm{nM})$ in actinic light $\left(\Phi_{\mathrm{PSII}} \mathrm{i} 1, \Phi_{\mathrm{PSII}} \mathrm{i} 6\right)$ and directly after the illumination period $\left(\Phi_{\mathrm{PSII}} \mathrm{r} 1\right)$. The recovery of PSII to the dark relaxed state, measured at the end ( $\Phi_{\text {PSII }}$ r5: Fig. 3 ) of the recovery time after the actinic light was switched off, was only affected in the plants exposed to the highest $\mathrm{Cu}$ concentration.

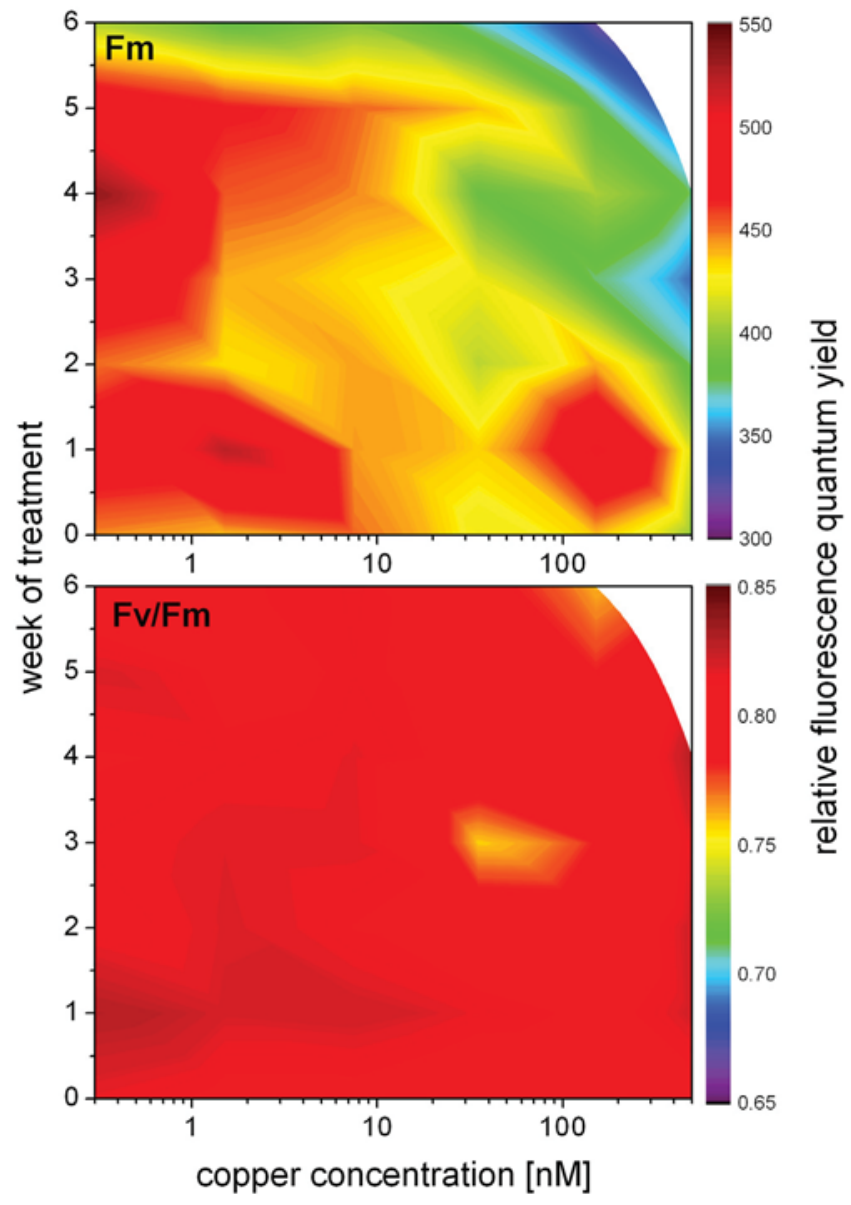

Fig. 2. Effect of $\mathrm{Cu}$ on the photosynthesis biophysics in Ceratophyllum demersum measured by in vivo chlorophyll fluorescence kinetic measurements. Values are given as means of four different experiments with two technical replicates each. Top: Effect on maximal fluorescence in dark-adapted samples $\left(\mathrm{F}_{\mathrm{m}}\right)$; Bottom: Effect on the maximal dark-adapted photochemical quantum yield of the photosystem II reaction centre measured as $F_{v} / F_{m}=\left(F_{m}-F_{0}\right) / F_{m}$.

There was a slight decrease in the non-photochemical quenching $(\mathrm{NPQ}=$ regulation of exciton dissipation as heat, measured as $\left(\left(\mathrm{F}_{\mathrm{m}}-\mathrm{F}_{\mathrm{m}^{\prime}}\right) / \mathrm{F}_{\mathrm{m}}\right)$ both in the light phase (NPQi1 and NPQi6) and in the dark phase (NPQr) (Fig. 3). NPQi1 was different in the more optimal concentrations $(7.5 \mathrm{nM})$ compared to the toxic ones $(150 \mathrm{nM}$; $\mathrm{P}=0.048$ ), while the decrease in the deficient $\mathrm{Cu}$ samples was not significant. The differences were not significant at the end of the actinic light phase (NPQi6, $\mathrm{P}=0.099$ ). At the beginning of the dark phase (NPQr1), differences were significant only between deficient and toxic $\mathrm{Cu}$ treatments $(0.3 \mathrm{nM}$ compared to $150 \mathrm{nM}, \mathrm{P}=0.02)$. The non-photochemical quenching at the end of the recovery time (NPQr5) did not change due to $\mathrm{Cu}$ exposure $(\mathrm{P}>0.15)$.

\subsection{Pigment composition}

The pigments were extracted from the harvested young and old plant tissues after six weeks of exposure to $\mathrm{Cu}$. The chlorophyll a (Chl a) content decreased towards toxic $\mathrm{Cu}$ concentrations with the highest $\mathrm{Cu}$ concentration showing the maximum decrease compared to the optimal $\mathrm{Cu}$ plant in the old plant tissue (Fig. 4). Significant differences were found only in the tissue from the highest $\mathrm{Cu}$ concentration. Interestingly, no change was observed in the $\mathrm{Chl} \mathrm{b}$ content. The other pigments yielded very noisy results (data not shown). Although [Cu]-Chl has a different absorption spectrum from that of $\mathrm{Mg}$-Chl, significant amounts of [Cu]-Chl can only be 

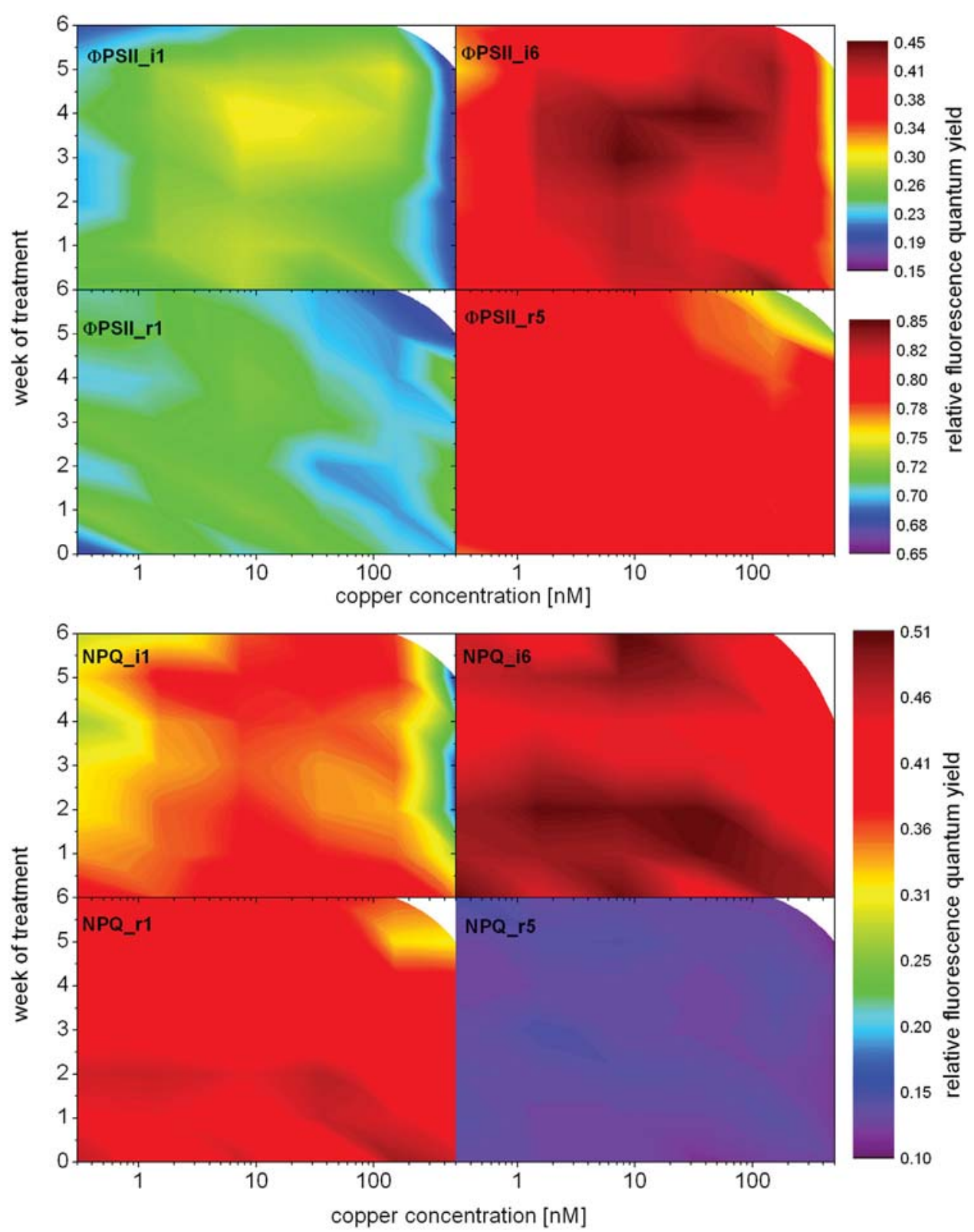

Fig. 3. Top: Effect of $\mathrm{Cu}$ on photochemical fluorescence quenching $\left(\Phi_{\mathrm{PSI}}\right)$ in Ceratophyllum demersum. $\Phi_{\mathrm{PSII}}$ indicates the light-acclimated electron flow through photosystem II measured as $\left(\Phi_{\mathrm{PSII}}=\left(\mathrm{F}_{\mathrm{m}}{ }^{\prime}-\mathrm{F}_{\mathrm{t}}{ }^{\prime}\right) / \mathrm{F}_{\mathrm{m}}{ }^{\prime}\right)$ at the beginning (i1) and end (i6) of the $200 \mathrm{~s}$ actinic light phase and at beginning ( $\left.\mathrm{r} 1\right)$ and end (r5) of the 200 s dark relaxation phase. Bottom: Effect of $\mathrm{Cu}$ on non-photochemical fluorescence quenching indicating the light-acclimated electron flow through photosystem $I I$ measured as $\left(\mathrm{NPQ}=\left(\mathrm{F}_{\mathrm{m}}-\mathrm{F}_{\mathrm{m}}{ }^{\prime}\right) / \mathrm{F}_{\mathrm{m}}\right)$ at the beginning (i1) and end (i6) of the $200 \mathrm{~s}$ actinic light phase and at beginning (r1) and end (r5) of the 200 s dark relaxation phase. Values are given as means of four different experiments with two technical replicates each. Note the different scale for $\Phi_{\text {PSII }}$ i1, i6, r1 on the one hand, and $\Phi_{\text {PSII }}$ r 5 on the other, for ease of comparison.

obtained at much higher $(\mu \mathrm{M}) \mathrm{Cu}$ concentrations with this method (Küpper et al., 2000, 2007b).

\subsection{Oxygen exchange}

Plants treated with optimum $\mathrm{Cu}(7.5 \mathrm{nM}-35 \mathrm{nM})$ had a higher photosynthesis rate already at the lowest light intensity compared to deficient and toxic $\mathrm{Cu}$ concentrations, and maximum photosynthesis rate at the highest applied light intensity (Fig. 5). The $\mathrm{Cu}$-deficient plants were saturated at the higher light intensities, yielding significant differences compared to the plants exposed to optimal Cu concentrations ( $\mathrm{DF}=4$ for $\mathrm{Cu}$ concentration, 8 for light intensity). The plants exposed to the highest $\mathrm{Cu}$ concentration died after 4 weeks of treatment and could not be measured. Respiration in the dark was measured before and after the light was provided and photorespiration calculated from the difference. Though there was a slight trend towards lower oxygen consumption towards higher $\mathrm{Cu}$ concentrations, the differences were not significant.

\subsection{Starch accumulation}

The starch content of the plant was measured after six weeks of treatment. At deficient $\mathrm{Cu}$ concentrations, plants had lower starch than those at optimal $\mathrm{Cu}$, while starch accumulation increased towards toxic $\mathrm{Cu}$ mainly in the old tissues. There was seemingly higher starch content in the younger parts of the plant compared to the old (Fig. 6). Due to the noise, the difference was not significant. 


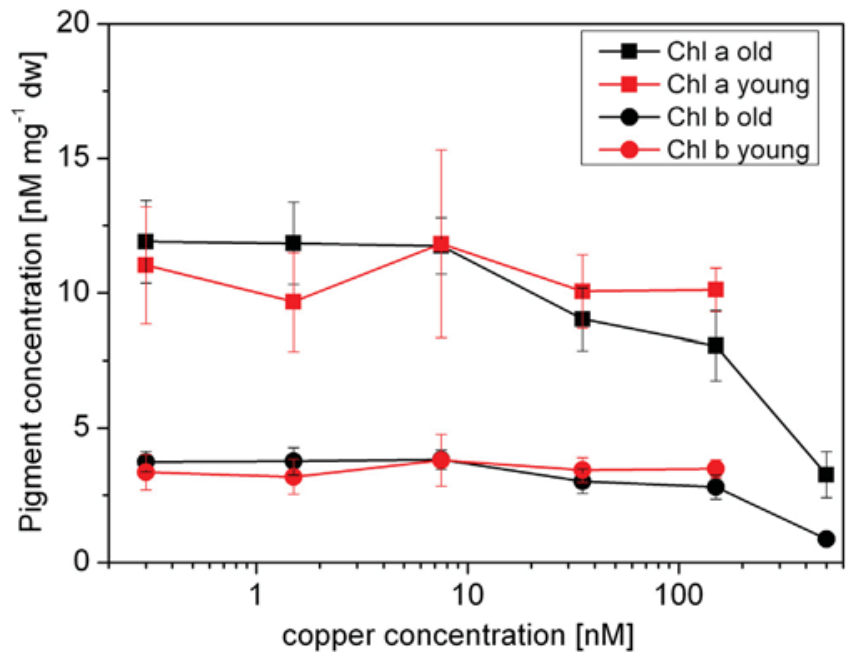

Fig. 4. Effect of $\mathrm{Cu}$ on $\mathrm{MgChl}$ a and $\mathrm{MgChl} \mathrm{b}$ in Ceratophyllum demersum after six weeks of treatment in the young and old tissues of the plants. Values are given as means $( \pm \mathrm{SE}, \mathrm{n}=4)$
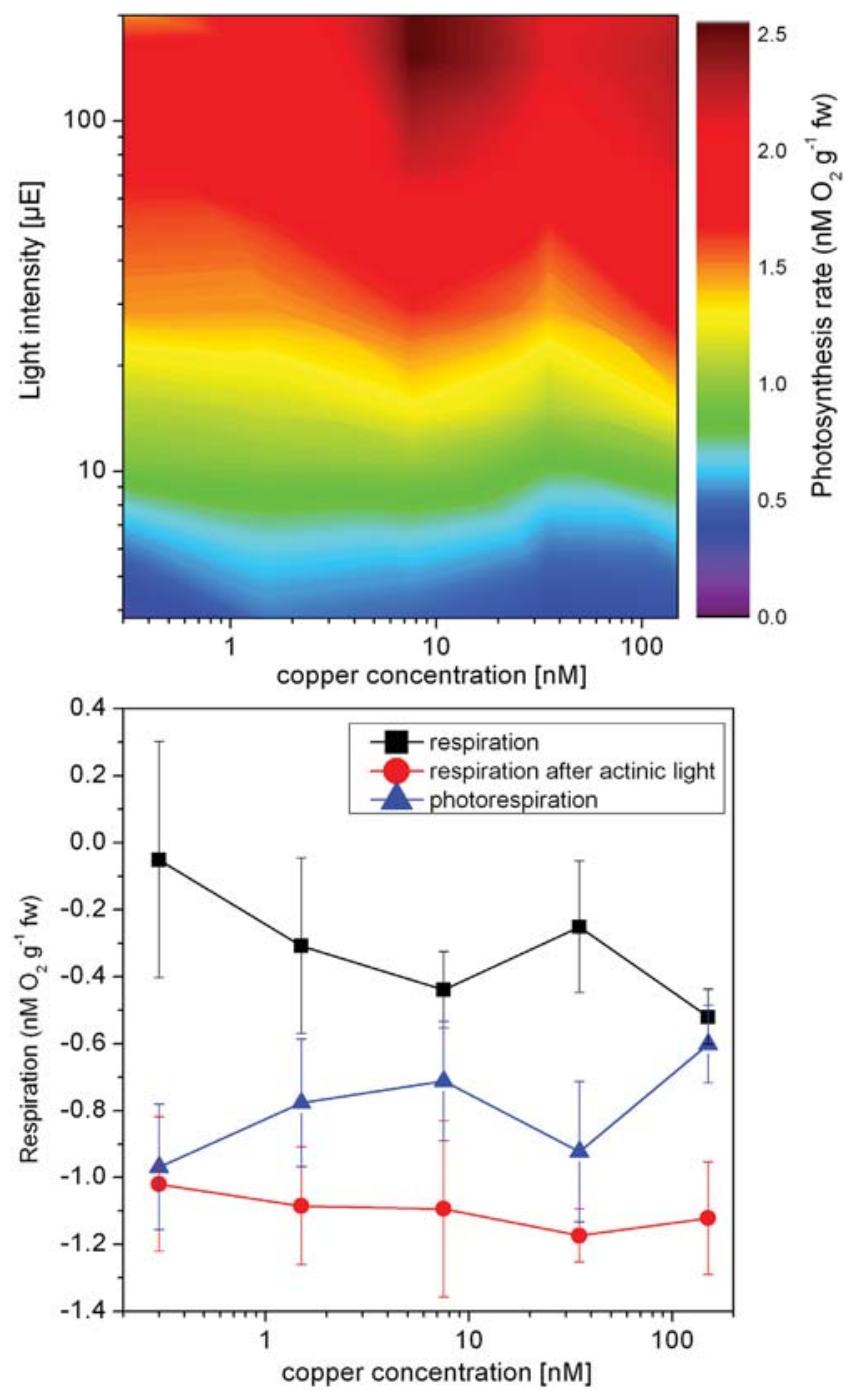

Fig. 5. Effect of $\mathrm{Cu}$ on the net photosynthetic oxygen release at increasing irradiances and respiration by Ceratophyllum demersum after six weeks of treatment. Values are given as means $( \pm \mathrm{SE}, \mathrm{n}=3)$.

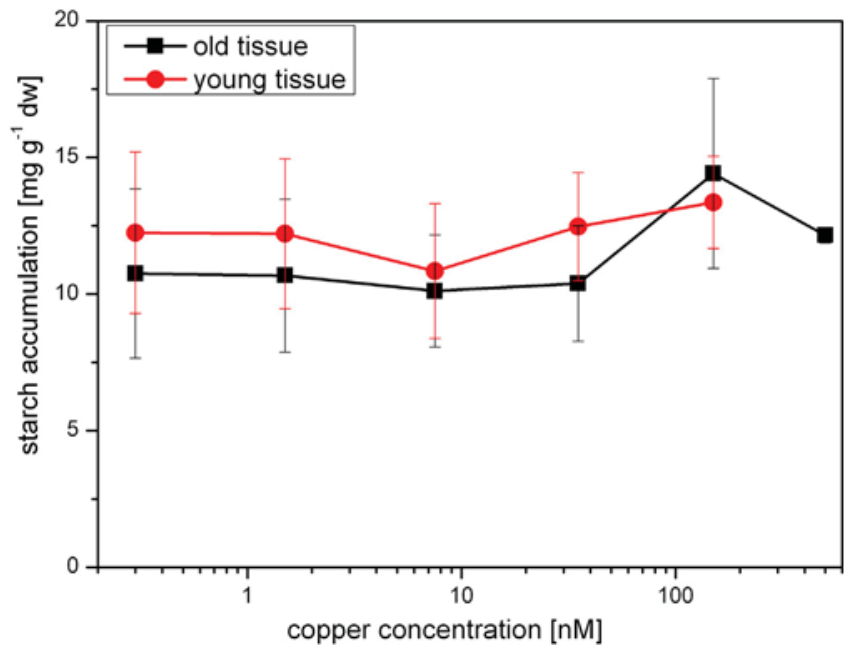

Fig. 6. Effect of $\mathrm{Cu}$ on the starch production or utilization of the young and old tissues of Ceratophyllum demersum after six weeks of treatment. Values are given as means ( \pm SE, $n=3$ ).

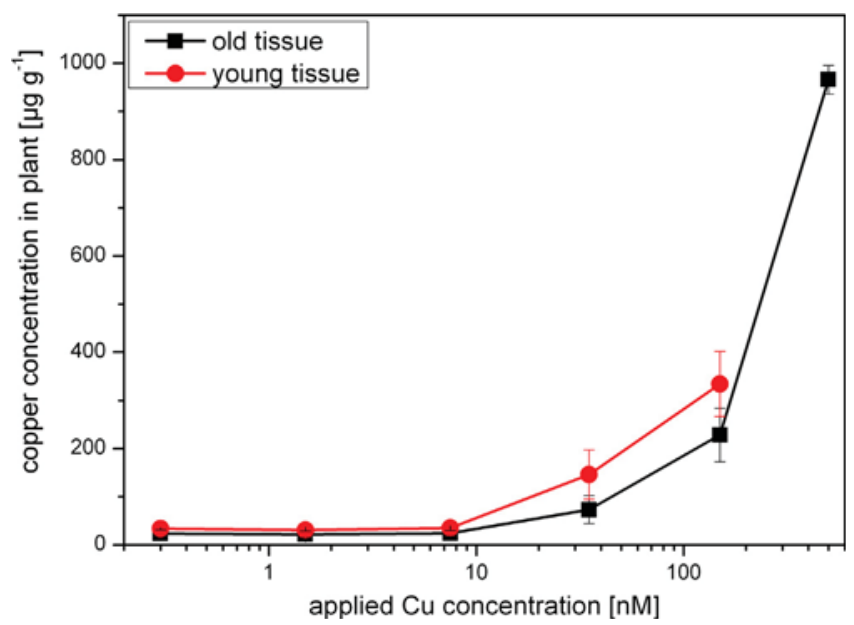

Fig. 7. Effect of $\mathrm{Cu}$ on the $\mathrm{Cu}$ accumulation in the young and old tissues of Ceratophyllum demersum after six weeks of treatment. Values are given as means $( \pm \mathrm{SE}$, $\mathrm{n}=4)$.

\subsection{Accumulation of copper}

Copper accumulation was determined in the harvested young and old parts of the plants (Fig. 7). Age and applied Cu concentration influenced the accumulation $(\mathrm{DF}=5$ and $\mathrm{P} \leq 0.001$ for $\mathrm{Cu}, \mathrm{DF}=1$ and $\mathrm{P}=0.006$ for age). The low $\mathrm{Cu}$ treatments (i.e. $0.3-7.5 \mathrm{nM}$ ) had accumulated approx. $23 \mathrm{ppm}$ in their old and $32 \mathrm{ppm}$ in their young tissues. There was a strong accumulation of $\mathrm{Cu}$ after $7.5 \mathrm{nM}$ with a threefold increase in the old and 4.5 -fold increase in the young tissue of the plants treated with $35 \mathrm{nM} \mathrm{Cu}$, which was significantly different from all lower concentrations. There was another threefold increase from $35 \mathrm{nM}$ to $150 \mathrm{nM}$ in the old to around $230 \mathrm{ppm}$, and a 2.3 -fold increase in the young tissues ( $330 \mathrm{ppm}$ ), significantly different from all other treatments. The highest concentration of $\mathrm{Cu}$ was found in the plants from the highest treatment (around $960 \mathrm{ppm}$ ). The young tissues had slightly more metal accumulation compared to the old tissues (Fig. 7).

\subsection{Metalloproteomics}

The Cu-containing proteins in soluble and membrane protein fractions were separated and identified using the size exclusion liq- 
uid chromatography coupled to ICP-MS and UV/Vis spectroscopy. We show one example each for deficient ("0" or $1 \mathrm{nM}$ ), optimal $(10 \mathrm{nM})$ and toxic $(100 \mathrm{nM}) \mathrm{Cu}$ concentrations.

In the soluble fraction, four $\mathrm{Cu}$ peaks were detected at 30,56 , 68 and 76 min corresponding to peak no. 1, 2, 3 and 4 respectively (Fig. 8). These peaks were present in all soluble fractions isolated from the different Cu treatments, even in the treatment without any $\mathrm{Cu}$ applied, showing a high affinity of those proteins for $\mathrm{Cu}$. Peak 1 had the highest protein content as observed from the UV-vis signal at all concentrations and represented all large molecules that could not be separated by the columns, but may also contain Ribulose1,5-bisphosphate carboxylase/oxygenase (RuBisCO; 540 kDa). Peak 2 could be identified by its molecular mass compared with the molecular weight marker and protein standard, as well as its $\mathrm{Cu}$ and $\mathrm{Zn}$ content, as superoxide dismutase (SOD; $35 \mathrm{kDa}$ ). Judging by its size and absorption spectrum at $597 \mathrm{~nm}$, plus its copper content, peak 3 corresponds to plastocyanin $(10.5 \mathrm{kDa})$. The last peak with an elution time of $76 \mathrm{~min}$, corresponding to a molecular mass $<1 \mathrm{kDa}$ could be some small ligands like phytochelatins. With increasing applied $\mathrm{Cu}$ concentration, the signal intensity of $\mathrm{Cu}$ in the three peaks increased, most obvious for peak 3, plastocyanin. However, there was hardly any change in the respective protein signal at $280 \mathrm{~nm}$ and $597 \mathrm{~nm}$.

In the membrane fractions, the ICPMS showed four peaks of $\mathrm{Cu}$ at approx. 15, 16.6, 18.5 and $22.3 \mathrm{~min}$, corresponding to peak no. 1, 2, 3 and 4, respectively (Fig. 9). The approximate molecular masses of the proteins corresponding to the major $\mathrm{Cu}$ peaks $1,2,3$, and 4 were $147 \mathrm{kDa}, 40 \mathrm{kDa}, 15.3 \mathrm{kDa}$ and $5 \mathrm{kDa}$. Note that there was no log-linear relationship of elution time and molecular mass of the standard for all masses. The additional and highest peaks of $\mathrm{Mg}$ and $\mathrm{Cu}$ after $25 \mathrm{~min}$ is considered to be "free" (aquocomplexed) ions and $\mathrm{Cu}$ and $\mathrm{Mg}$ ions bound to small molecules, including components from the mobile phase.

By their elution sequence, absorption spectra, and Mg content, the four protein peaks eluted between 13 and 17 min could be identified as the supercomplexes of PSI and PSII, and the major antennae of PSII, the LHCII trimers and LHCII monomers (Galka et al., 2012; Andresen et al., 2016). The identification of these peaks was confirmed by mass spectrometry in a previous study on Cd toxicity (Andresen et al., 2016). The latter two peaks (LHCIIs) corresponded with the Cu signal depicted as Peak 1 and 2 (Fig. 9), suggesting $\mathrm{Cu}$ binding to the LHCII trimers and monomers. Peak 3 and 4 , yet unidentified Cu-binding proteins, had higher signal intensities of $\mathrm{Cu}$, but lower protein absorbances, demonstrating a high affinity binding site.

Despite a lot of effort, the plants exposed to "0" $\mathrm{nM} \mathrm{Cu}$ had as much $\mathrm{Cu}$ in the membrane fraction as the plants from the $10 \mathrm{nM}$ $\mathrm{Cu}$ treatment and even more unspecific "free" $\mathrm{Cu}$, suggesting $\mathrm{Cu}$ leaching from the HPLC system. The plants exposed to $>10 \mathrm{nM} \mathrm{Cu}$ concentrations had increasing $\mathrm{Cu}$ signal intensities.

\section{Discussion}

The whole range of responses of the aquatic model plant Ceratophyllum demersum to $\mathrm{Cu}$ from deficient, via optimal to toxic $\mathrm{Cu}$ concentrations under low light conditions was studied using a large array of biophysical and biochemical methods. The $\mathrm{Cu}$ concentration range between $7.5 \mathrm{nM}$ and $35 \mathrm{nM}$ was noted as the optimum for the proper growth and functioning of the plant as observed from the responses of the physiological parameters in these plants when compared to other $\mathrm{Cu}$ concentrations. With a lot of effort, a nearly Cu-less environment was prepared for the plants, yielding responses of $\mathrm{Cu}$ deficiency. The different responses to deficiency and toxicity are discussed below.

\subsection{Copper deficiency}

Copper deficiency was associated with a decrease in growth rate, which never became negative because of the residual copper that could not be eliminated from the system despite all efforts described in the methods. The growth inhibition was much more severe under high light conditions, as described previously (Thomas et al., 2013). However, also under low light conditions the growth rate decreased with longer treatment duration, because the plants can utilize an internal reserve of $\mathrm{Cu}$ for their normal functions during the initial weeks. When this internal $\mathrm{Cu}$ is consumed, deficiency symptoms occur, affecting the growth. There could also be a release of copper from the plant tissues into the nutrient solution if the $\mathrm{Cu}^{2+}$ concentration in the nutrient solution is below $10 \mathrm{nM}$ as shown in the high light experiment (Thomas et al., 2013), which indicated that $C$. demersum does not have copper transporters suitable to achieve an active uptake below this threshold concentration.

High light stress along with the $\mathrm{Cu}$ deficiency would exacerbate oxidative stress (Yu and Rengel 1999). The Cu deficiency in these conditions leads to a disruption of the carbon assimilation and/or impairment of the photosynthate transport which further increases the production of reactive oxygen species (ROS) (Bowler et al., 1992). These effects are likely responsible for the negative growth rate in high light conditions (Thomas et al., 2013) and the lack of a clear growth inhibition under low light conditions (Fig. 1).

In Cu-deficient conditions, electron flow in actinic light between PSI and PSII became limiting. Both $\Phi_{\text {PSII }} \mathrm{i} 1$ and $\Phi_{\text {PSII }} \mathrm{i} 6$ (Fig. 3) decreased at deficient copper towards the end of the treatment period, suggesting the impairment of the electron transport chain due to lack of $\mathrm{Cu}$-containing plastocyanin, while no inhibition of the photochemical yield of PSII $\left(\mathrm{F}_{\mathrm{v}} / \mathrm{F}_{\mathrm{m}}\right)$ by copper deficiency was found (Fig. 2).

The $\mathrm{Cu}$ peak 3 in the soluble fraction (with molecular weight and specific UV-vis signals at $597 \mathrm{~nm}$ both corresponding to plastocyanin) was slightly lower, however, still visible at deficient $\mathrm{Cu}$ concentrations (Fig. 8), compared to sufficient Cu concentrations. This could indicate a decrease in the amount of plastocyanin or removal of $\mathrm{Cu}$ from the active centre of the protein, as plastocyanin is much less stable without $\mathrm{Cu}$ (Abdel-Ghany et al., 2005; Shikanai et al., 2003).

This and also an earlier study (Baszynski et al., 1978) suggests that $\mathrm{Cu}$ deficiency hampers the plastocyanin formation and functioning, which in turn reduces the electron transport from PSII to PSI both in high light (Thomas et al., 2013) and low light conditions (this study). An internal rescue of the photosynthetic electron carrier plastocyanin was achieved by down-regulation of SOD in Arabidopsis, thereby making the $\mathrm{Cu}$ available to plastocyanin (Abdel-Ghany and Pilon, 2008). Accordingly it was found that the Fe-SOD gene was strongly induced in Arabidopsis while the $\mathrm{Cu} / \mathrm{Zn}-\mathrm{SOD}$ gene was down-regulated (Abdel-Ghany et al., 2005; Yamasaki et al., 2007; Cohu and Pilon, 2007). The molecular mechanisms of the downregulation of $\mathrm{Cu}$-proteins, including $\mathrm{Cu} / \mathrm{Zn}-\mathrm{SOD}$, are accomplished by expression of $\mathrm{Cu}$-microRNAs which promote the degradation of respective transcripts of the $\mathrm{Cu}$-proteins, as recently reviewed by Piug (2014).

The blockage of the electron transport due to hampering of the plastocyanin as a result of Cu deficiency leaves more electrons to contribute to the formation of excess ROS during normal physiological conditions (when the production and scavenging of ROS are regulated well), thus increasing oxidative stress (Ayala and Sandmann 1988). In our study, there was no obvious change in the $\mathrm{Cu} / \mathrm{Zn}$-SOD related peaks (Fig. 8, peak 2) at deficient, optimal, or toxic $\mathrm{Cu}$ concentrations. Most likely due to the anyhow low abundance of the SOD in the protein profile, no decrease or increase was observed. However, not only the amount of SOD could be influenced, but also the activity as observed in Lemna gibba (Vaughan 

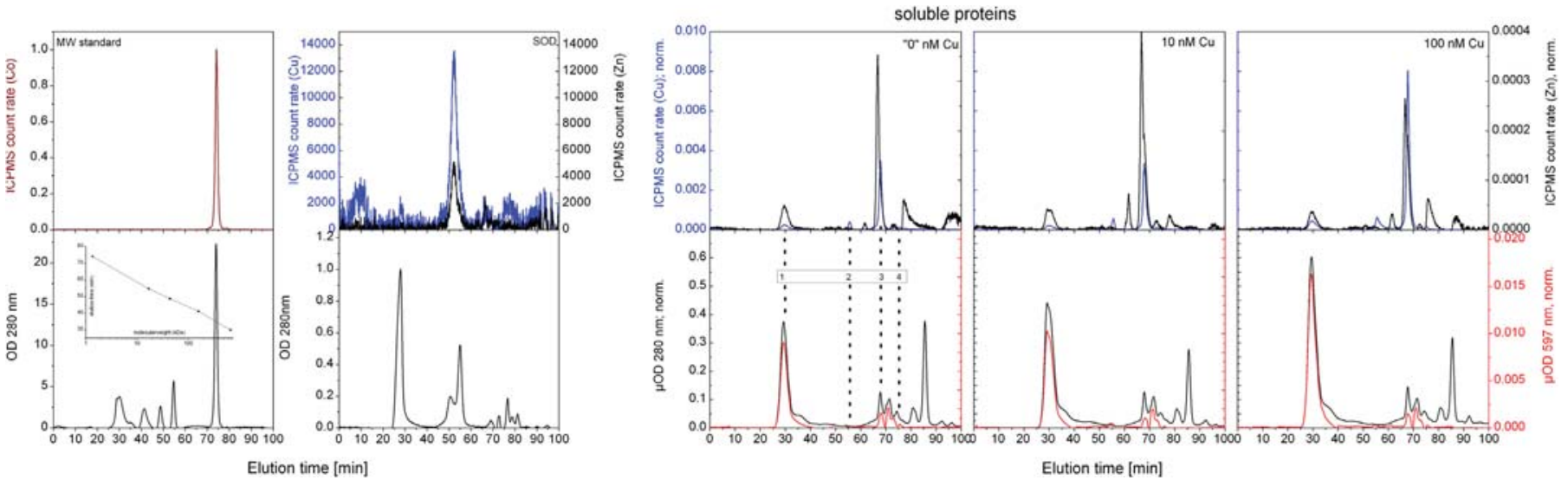

Fig. 8. Effect of deficient, optimal and toxic Cu concentration on the soluble proteins of Ceratophyllum demersum. ICPMS count rates for Cu (left scale, blue), and Zn (right scale, black) and UV/Vis absorption chromatogram at $280 \mathrm{~nm}$ to detect all proteins (left scale, black) and $597 \mathrm{~nm}$ to detect blue copper proteins (right scale, red) were normalized to the amount of free $\mathrm{Mg}^{2+}$ in each sample (norm.). Major Cu containing peaks are highlighted and labelled (1-4) in sample "0" nM. The molecular weight standard together with the Co signal as well as protein chromatogram and $\mathrm{Cu}$ and $\mathrm{Zn}$ signal of SOD are shown. Chromatograms from one of three experiments are shown as examples. (For interpretation of the references to colour in this figure legend, the reader is referred to the web version of this article.)
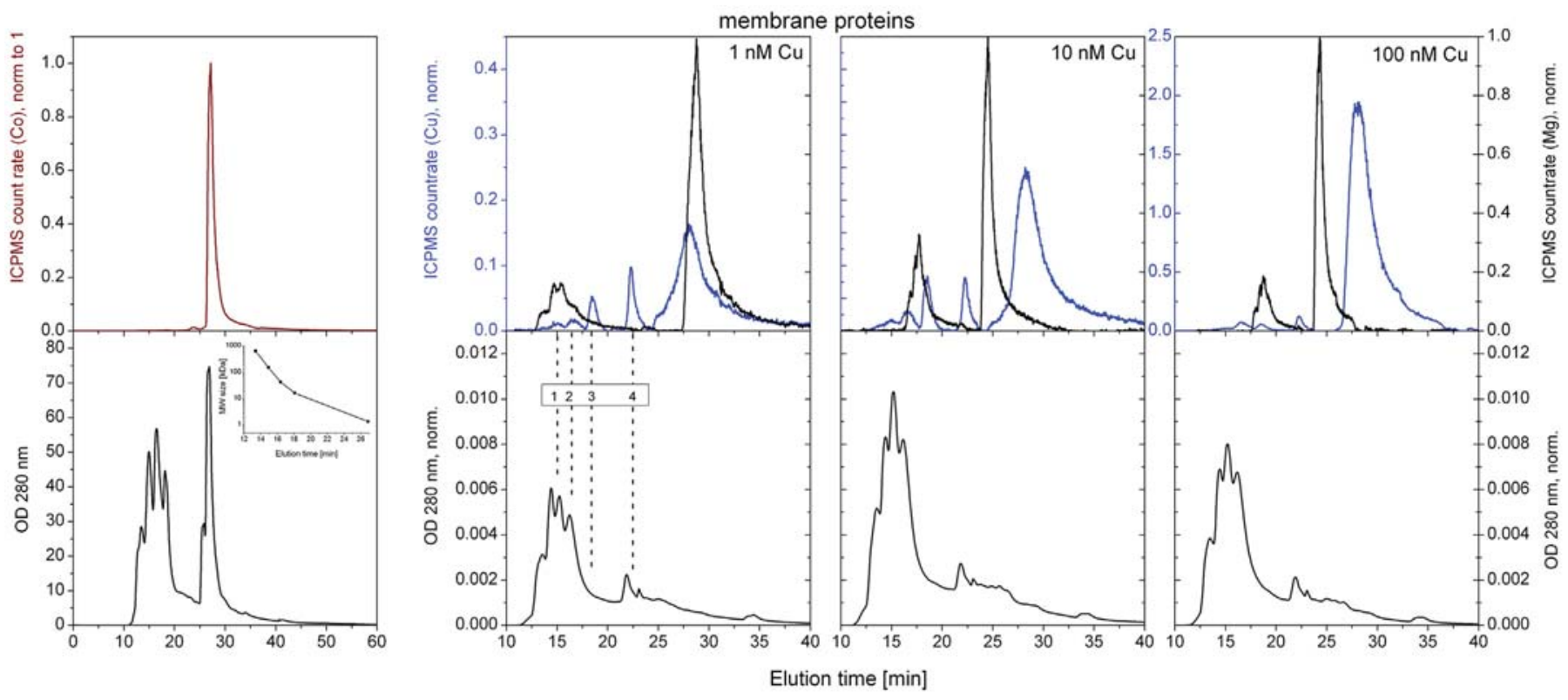

Fig. 9. Effect of deficient, optimal and toxic Cu concentration on membrane proteins of $C$. demersum. Protein chromatogram at $280 \mathrm{~nm}$ and ICPMS count rates for Cu (left scale, blue), and $\mathrm{Mg}$ (right scale, black) were normalized to the amount of free $\mathrm{Mg}^{2+}$ in each sample (norm.). Note the different scale for Cu in samples from $100 \mathrm{nM} \mathrm{Cu}$. Major $\mathrm{Cu}$ containing peaks are highlighted and labelled (1-4) in sample $1 \mathrm{nM}$. The molecular weight standard together with the Co signal is shown. Chromatograms from one of three experiments are shown as examples. (For interpretation of the references to colour in this figure legend, the reader is referred to the web version of this article.)

et al., 1982), leaves of Phaseolus vulgaris (Cakmak and Marschner, 1993). The Cu-deficient plant's ability to substitute Cu-proteins with proteins of similar or overlapping function but different central ion has been proposed (Puig et al., 2007). An increase in the Mn-SOD and Fe-SOD activity during Cu deficiency in tobacco plants (Yu et al., 1998) supported the earlier study. But the different subcellular localization of the SOD forms ( $\mathrm{Cu} / \mathrm{Zn}$-SOD commonly found in the cytosol, Mn-SOD in mitochondria and Fe-SOD in chloroplast) questions the above stated substitution of the Cu proteins to replace their local functioning (Van Camp et al., 1996). Some other Cu containing proteins like diamine oxidase (DAO) and ascorbate oxidase (AO) were shown to decrease during Cu deficiency (Loneragan et al., 1982). It was found that the apo-protein was initially synthesized (Salam 2001), but in the absence of Cu rapidly degraded by specific proteases. During Cu deficiency a greater decrease in the activity of the AO than the SOD was reported (Salam 2001), probably indicating that the plants prioritise the ROS detoxification (Foyer et al.,
1994) by making the available Cu for SOD activity as a mechanism to combat the oxidative stress over the ascorbate metabolism. Ascorbate oxidase and diamine oxidase are not abundant $\mathrm{Cu}$ proteins and were not detected in our metalloproteomics approach.

\subsection{Copper toxicity}

From earlier studies, even though toxicity thresholds vary between plant species, the inhibitory effects were visible when the plant $\mathrm{Cu}$ concentrations were higher than $20 \mathrm{ppm}$ (Gupta, 1979; Stevenson, 1986; Marschner, 1995). In this study as well, the plants exposed to $\mathrm{Cu}$ concentrations up to $10 \mathrm{nM}$ ( $7.5 \mathrm{nM}$ averaged) in the nutrient solution had an internal $\mathrm{Cu}$ concentration of around $20 \mathrm{ppm}$ (Fig. 7). At higher copper concentrations, i.e. already directly above the optimum $\mathrm{Cu}$ concentration (as determined from the growth rate and our earlier study), accumulation of $\mathrm{Cu}$ in the plant increased drastically (Fig. 7). The Cu peaks associated with the 
proteins increased vastly from this threshold in both the soluble (Fig. 8) and membrane fractions (Fig. 9, e.g. maximum of normalized ICPMS count rate for $\mathrm{Cu} 10 \mathrm{nM}$ : 0.25 , for $20 \mathrm{nM}$ : 0.47 , for $50 \mathrm{nM}$ : 0.9 etc.). However, visible symptoms like growth reduction and shrinking (Fig. 1), as well as decreased values for photosynthesis biophysics (Fig. 2, Fig. 3) occurred only towards the highest applied Cu concentrations.

Comparing these results with our earlier study under high light conditions, it is obvious that the light regime plays an important role in the toxicity. In high light, the toxicity revealed itself with visible toxicity symptoms and growth damage in $\mathrm{Cu}$ concentrations higher than $50 \mathrm{nM}$ after six weeks while these symptoms were not observed in low light conditions until the highest ( $500 \mathrm{nM}) \mathrm{Cu}$ concentration. The growth rate of these plants decreased from the first week of treatment (Fig. 1), associated with a decrease in chlorophyll (Fig. 4) and loss of leaves from the stem (data not shown). The plants were dead after four weeks of treatment.

Before the winter, the macrophyte $C$. demersum forms a specialised overwintering bud produced in response to unfavourable conditions including decreasing day light or reduced temperature, and sink to the bottom of the water (Best 1977). Before actual winter conditions, starch accumulation increased so that the plants could use the carbohydrate to survive the dormant period (Best and Visser 1987). The low light conditions used in this experiment would be autumn/partial winter conditions limited by light (both intensity and duration) and therefore led to a decrease in starch accumulation when compared to high light (Thomas et al., 2013).

Copper accumulated more in the younger than in the older parts of the plant (Fig. 7). This stronger uptake in metabolically more active parts of the plant as shown by the generally higher starch contents in young compared to old tissues (Fig. 6) indicates that copper was actively taken up at all $\mathrm{Cu}$ concentrations, the deficient, optimal and toxic Cu treatments.

There is a well known connection between Fe homeostasis and excess of other metals (e.g. Cu, Cd, Basa et al., 2014; Pätsikkä et al., 2002) and correspondingly, elevated Cu can inhibit Fe uptake (Puig et al., 2007; Peng et al., 2013). Iron is needed for the cytochrome complexes, ferredoxin, and intermediates of the thylakoid electron transport chain (Spiller and Terry, 1980). Even if Cu ions do not replace $\mathrm{Fe}$ in those centres, the $\mathrm{Cu}$-induced lack of $\mathrm{Fe}$ in those complexes can have consequences for the photosynthetic performance of the plants. Although most Chl fluorescence originates from PSIl when measured at physiological conditions (like room temperature etc., (reviewed by Harbinson and Rosenqvist 2003)), changes in and damage to PSI can influence the fluorescent output of PSII. A "traffic jam" of electrons results because damaged PSI initiates the rearrangement of the antenna systems between PSI and PSII. This so-called state transition (reviewed by Minagawa 2011) reduces the amount of electrons transferred from PSII to PSI. Furthermore, Fe-limitation leads to destabilisation of the Fe-S-clusters in PSI, and thereby their degradation (Amann et al., 2004). This could further influence the fluorescence output. However, all metal toxicity studies we are aware of show a higher degree of damage to PSII compared to PSI, and those showing inhibition of PSI were often carried out using unnaturally high metal concentrations (reviewed by Küpper and Andresen, 2016).

As visible from the metalloproteomics data, $\mathrm{Cu}$ was found in the peaks corresponding to the photosynthetic complexes (Fig. 9, Peak 1 and 2). Although during the procedure of protein isolation, a certain amount of $\mathrm{Cu}$ will bind to proteins that were $\mathrm{Cu}$-free in vivo, our data show that $\mathrm{Cu}$ potentially binds to the photosynthetic complexes by replacing $\mathrm{Mg}$ in the $\mathrm{Chl}$ molecules. The formation of [Cu]-Chl and [Zn]-Chl was shown to take place mainly in the LHCIIs under low light conditions, while in high irradiance it was suggested to take place in the PS II reaction centres (Küpper et al., 2002, 2006). Furthermore, recently the insertion of $\mathrm{Cd}^{2+}$ in the LHCIIs was shown to occur with high efficiency (apparent $K_{D}=10.5 \mathrm{nM}$ ) in $\mathrm{Cd}$-stressed $C$. demersum plants, which previously had only been postulated as [Cd]-Chl is highly unstable and has a very similar UV/VIS absorption spectrum as Mg-Chl (Andresen et al., 2016).

One important difference between low light and high light grown plants is that low light grown plants have generally bigger antenna systems with more antenna proteins (LHCIIs) per reaction centre (RC) (Taiz and Zeiger, 2007). Following this, low light grown plants possess more Chls as potential binding sites for $\mathrm{Cu}$, the formation of [Cu]-Chl within the LHCIIs is more likely than in the PSII-RCs. Further, it has been shown that in high irradiance the Chls in LHCII of Chlorophyta are inaccessible to formation of heavy metal substituted Chls ([hms]-Chls). Thus, high light conditions favour the formation of [hms]-Chl (incl. [Cu]-Chl) within the PSII-RC, presumably into the pheophytin (Küpper et al., 2002). This is most detrimental for the plant, because the whole photosystem is lost, visible by a prominent decrease of $\mathrm{F}_{\mathrm{v}} / \mathrm{F}_{\mathrm{m}}$, as observed under high light conditions (Thomas et al., 2013), but not under low light conditions (Fig. 2). Changes in $\mathrm{F}_{\mathrm{v}} / \mathrm{F}_{\mathrm{m}}$ cannot be detected when both $\mathrm{F}_{0}$ and $\mathrm{F}_{\mathrm{m}}$ change, e.g. because of a general reduction in Chl. However, even in the LHCIIs [Cu]-Chl is unsuitable for photosynthesis. [Cu]$\mathrm{Chl}$ does not bind axial ligands, changing the confirmation of the pigment-protein complex (reviewed by Küpper et al., 2006; Janik et al., 2010). Even worse, upon excitation [Cu]-Chl does not transfer the excitons to other chlorophylls, but releases the energy as heat (it is non-fluorescent). This usually leads to a decrease in the total fluorescence amplitudes, but not necessarily to a decrease of $\mathrm{F}_{\mathrm{v}} / \mathrm{F}_{\mathrm{m}}$ (Fig. 2, Küpper et al., 2006). In the current study, only a small amount of Chls in the LHCIIs were subjected to heavy metal substitution, leaving enough Mg-Chls to transfer the excitons to the RCs that the plants were still viable up to $200 \mathrm{nM} \mathrm{Cu}$. In our data we observed a decrease in the fluorescence parameters including $\mathrm{F}_{\mathrm{v}} / \mathrm{F}_{\mathrm{m}}$ towards highly toxic copper concentrations (Fig. 2) and $\Phi_{\text {PSII }}$ (Fig. 3) along with a decrease of Chl a (Fig. 4) and much less changes in NPQ (Fig. 3). None of these changes were as prominent as under high light conditions (Thomas et al., 2013), verifying that damage to LHCII complexes is far less detrimental to the plants as damage to the PS II RC.

\section{Conclusions}

Optimal growth, highest photosynthesis rate and highest operating efficiency of PSII ( $\Phi_{\text {PSII }}$ ) was found between $7.5 \mathrm{nM}$ and $35 \mathrm{nM}$, but the photosynthetic quantum efficiency of the PSII reaction centre $\left(\mathrm{F}_{\mathrm{v}} / \mathrm{F}_{\mathrm{m}}\right)$ had its highest value between $1.5 \mathrm{nM}$ and $7.5 \mathrm{nM} \mathrm{Cu}$. Respiration was not affected by the $\mathrm{Cu}$ treatment indicating that in Ceratophyllum demersum, photosynthesis is more sensitive to $\mathrm{Cu}$ toxicity compared to other metabolic pathways. Under Cu deficiency, the lack of the Cu-containing electron carrier plastocyanin decreased the photosynthetic performance. The detection of $\mathrm{Cu}$ in the $\mathrm{Chl}$ peaks in metalloproteomics analyses suggests the generation of [Cu]-Chl, unsuitable for photosynthesis. All described effects were more pronounced in our previous study conducted under high light conditions, emphasizing the buffering role of $\mathrm{Cu}$ binding to the LHCIIs.

\section{Acknowledgments}

We are grateful for the financial support by the Deutsche Forschungsgemeinschaft (grants KU 1495/8 and 1495/7) and basic funding of Universität Konstanz and Biology Centre of the Czech Academy of Sciences to HK, as well as grant MŠMT No. LM2015075 to TH. Initial work by GT in the lab of HK was supported by the DAAD (IAESTE programme). We also thank Melanie Gerigk and Hanna Borlinghaus for indispensible help with C. demersum stock cultures 
and Jakub Borovec for providing measuring time at his HPLC-ICPMS system.

\section{References}

Abdel-Ghany, S.E., Pilon, M., 2008. MicroRNA-mediated systemic down- regulation of copper protein expression in response to low copper availability in Arabidopsis. J. Biol. Chem. 283, 15932-15945.

Abdel-Ghany, S.E., Müller-Moulé, P., Niyogi, K.K., Pilon, M., Shikanai, T., 2005. Two P-type ATPases are required for copper delivery in Arabidopsis thaliana chloroplasts. Plant Cell 117, 1233-1251.

Amann, K., Lezhneva, L., Wanner, G., Herrmann, R.G., Meurer, J., 2004. ACCUMULATION OF PHOTOSYSTEM ONE1, a member of a novel gene family, is required for accumulation of [4Fe-4S] cluster-containing chloroplast complexes and antenna proteins. Plant Cell 16, 3084-3097.

Andresen, E., Mattusch, J., Wellenreuther, G., Thomas, G., Abad, U.A., Küpper, H., 2013a. Different strategies of cadmium detoxification in the submerged macrophyte Ceratophyllum demersum L. Metallomics 5, 1377-1386.

Andresen, E., Opitz, J., Thomas, G., Stärk, H.-J., Dienemann, H., Jenemann, K., Dickinson, B.C., Chang, C.J., Küpper, H., 2013b. Effects of Cd \& Ni toxicity to Ceratophyllum demersum under environmentally relevant conditions in soft $\&$ hard water including a German lake. Aquat. Toxicol. 142-143, 387-402.

Andresen, E., Kappel, Š., Stärk, H.-J., Riegger, U., Borovec, J., Mattusch, J., Heinz, A., Schmelzer, C.E.H., Matoušková, Š., Dickinson, B., Küpper, H., 2016. Cadmium toxicity investigated at the physiological and biophysical levels under environmentally relevant conditions using the aquatic model plant Ceratophyllum demersum. New Phytol., http://dx.doi.org/10.1111/nph.13840.

Asada, K., 2006. Production and scavenging of reactive oxygen species in chloroplasts and their function. Plant Physiol. 141, 391-396.

Ayala, M.B., Sandmann, G., 1988. Activities of $\mathrm{Cu}-$ containing proteins in Cu-depleted pea leaves. Physiol. Plantarum 72, 801-806.

Baccini, P., 1985. Metal transport and metal/biota interactions in lakes. Environ. Technol. Lett. 6, 327-334.

Basa, B., Lattanzio, G., Solti, Á., Tóth, B., Abadía, J., Fodor, F., Sárvári, É., 2014 Changes induced by cadmium stress and iron deficiency in the composition and organization of thylakoid complexes in sugar beet (Beta vulgaris L.) Environ. Exp. Bot. 101, 1-11.

Baszynski, T., Ruszkowska, M., Król, M., Tukendorf, A., Wolinska, D., 1978. The effect of copper deficiency on the photosynthetic apparatus of higher plants. Z. Pflanzenphysiol. 89, 207-216.

Best, E.P.H., Visser, H.W.C., 1987. Seasonal growth of the submerged macrophyte Ceratophyllum demersum L. in mesotrophic Lake Vechten in relation to insolation, temperature and reserve carbohydrates. Hydrobiologia 148 231-243.

Best, E.P.H., 1977. Seasonal changes in mineral and organic components of Ceratophyllum demersum and Elodea canadensis. Aquat. Bot. 3, 337-348.

Bowler, C., Van Montagu, M., Inze, D., 1992. Superoxide dismutase and stress tolerance. Annu. Rev. Plant Physiol. 43, 83-116.

Bussler, W., 1981. Physiological functions and utilization of copper. In: Loneragan, J.F., Robson, A.D., Graham, R.D. (Eds.), Copper in Soils and Plants. Academic Press, New York, pp. 213-234.

Cakmak, I., Marschner, H., 1993. Effect of zinc nutritional status on activities of superoxide radical and hydrogen peroxide scavenging enzymes in bean. Plant Soil 156, 127-130.

Cohu, C., Pilon, M., 2007. Regulation of superoxide dismutase expression by copper availability. Physiol. Plantarum 129, 747-755.

Delhaize, E., Lonergan, J.F., Webb, J., 1985. Development of three copper metalloenzymes in clover leaves. Plant Physiol. 78, 4-7.

Delhaize, E., Dilworth, M.J., Webb, J., 1986. The effects of copper nutrition and developmental state on the biosynthesis of diamine oxidase in clover leaves. Plant Physiol. 82, 1126-1131.

Droppa, M., Masojidek, J., Rózsa, Z., Wolak, A., Horváth, L.I., Farkas, T., Horváth, G., 1987. Characteristics of Cu deficiency-induced inhibition of photosynthetic electron transport in spinach chloroplasts. Biochim. Biophys. Acta: Bioenerg. 891, 75-84.

Foyer, C.H., Descourivieres, P., Kunert, K.J., 1994. Protection against oxygen radicals: an important defence mechanism studied in transgenic plants. Plant Cell Environ. 17, 507-523

Galka, P., Santabarbara, S., Huong Khuong, T.T., Degand, H., Morsomme, P., Jennings, R.C., Boekema, E.J., Caffarri, S., 2012. Functional analyses of the plant photosystem I-light-harvesting complex II supercomplex reveal that light-harvesting complex II loosely bound to photosystem II is a very efficient antenna for photosystem I in state II. Plant Cell 24, 2963-2978.

Genty, B., Briantais, J., Baker, N.R., 1989. The relationship between the quantum yield of photosynthetic electron-transport and quenching of chlorophyll fluorescence. Biochim. Biophys. Acta 990, 87-92.

Gupta, U.C., 1979. Copper in agricultural crops. In: Nriagu, J.O. (Ed.), Copper in the Environment. Part I: Ecological Cycling. John Wiley \& Sons Inc, New York, pp. $255-288$.

Harbinson, J., Rosenqvist, E., 2003. An introduction to chlorophyll fluorescence. In: DeEll, J., Toivonen, P.M.A. (Eds.), Practical Applications of Chlorophyll Fluorescence in Plant Biology. Springer Science + Business Media, New York, pp. 1-29.
Janik, E., Maksymiec, W., Mazur, R., Garstka, M., Gruszecki, W.I., 2010. Structural and functional modifications of the major light-harvesting complex II in cadmium or copper-treated Secale cereale. Plant Cell Physiol. 51, 1330-1340.

Küpper, H., Andresen, E., 2016. Mechanisms of metal toxicity in plants. Metallomics 8, 269-285.

Küpper, H., Kroneck, P.M.H., 2005. Heavy metal uptake by plants and cyanobacteria. In: Sigel, A., Sigel, H., Sigel, R.K.O. (Eds.), Metal Ions in Biological Systems. Marcel Dekker, New York, pp. 97-142.

Küpper, H., Küpper, F., Spiller, M., 1996. Environmental relevance of heavy metal substituted chlorophylls using the example of submersed water plants. J. Exp. Bot. 47, 259-266.

Küpper, H., Küpper, F., Spiller, M., 1998. In situ detection of heavy metal substituted chlorophylls in water plants. Photosynth. Res. 58, 123-133.

Küpper, H., Spiller, M., Küpper, F.C., 2000. Photometric method for the quantification of chlorophylls and their derivatives in complex mixtures: fitting with Gauss-Peak-Spectra. Anal. Biochm. 286, 247-256.

Küpper, H., Šetlík, I., Spiller, M., Küpper, F.C., Prášil, O., 2002. Heavy metal-induced inhibition of photosynthesis: targets of in vivo heavy metal chlorophyll formation. J. Phycol. 38, 429-441.

Küpper, H., Küpper, F., Spiller, M., 2006. Heavy metal]-chlorophylls formed in vivo during heavy metal stress and degradation products formed during digestion, extraction and storage of plant material. In: Grimm, B., Porra, R., Rüdiger, W., Scheer, H. (Eds.), Chlorophylls and Bacteriochlorophylls: Biochemistry, Biophysics, Functions and Applications, 41. Kluwer Academic Publishers, Dordrecht, pp. 67-77, 395-403.

Küpper, H., Aravind, P., Leitenmaier, B., Trtílek, M., Šetlík, I., 2007a. Cadmium-induced inhibition of photosynthesis and long-term acclimation to Cd-stress in the Cd hyperaccumulator Thlaspi caerulescens. New Phytol. 175, 655-674.

Küpper, H., Seibert, S., Aravind, P., 2007b. A fast, sensitive and inexpensive alternative to analytical pigment HPLC: quantification of chlorophylls and carotenoids in crude extracts by fitting with Gauss-Peak-Spectra. Anal. Chem. 79, 7611-7627.

Küpper, H., Šetlík, I., Seibert, S., Prášil, O., Šetlikova, E., Strittmatter, M., Levitan, O., Lohscheider, J., Adamska, I., Berman-Frank, I., 2008. Iron limitation in the marine cyanobacterium Trichodesmium reveals new insights into regulation of photosynthesis and nitrogen fixation. New Phytol. 179, 784-798.

Kabata-Pendias, A., Pendias, H., 1984. Trace Elements in Soils and Plants. CRC Press, Boca Raton Florida.

Lipman, C.B., McKinney, G., 1931. Proof of the essential nature of copper for higher green plants. Plant Physiol. 6, 539-599.

Loneragan, J.F., Delhaize, E., Webb, J., 1982. Enzyme diagnosis of copper deficiency in subterranean clover. I. Relationship of ascorbate oxidase activity in leaves to plant copper status. Aust. J. Agric. Res. 33, 967-979.

Marschner, H., 1995. Mineral Nutrition of Higher Plants. Academic Press, London.

Minagawa, J., 2011. State transitions -The molecular remodeling of photosynthetic supercomplexes that controls energy flow in the chloroplast. Biochim. Biophys. Acta 1807, 897-905.

Mishra, S., Srivastava, S., Tripathi, R.D., Trivedi, P.K., 2008. Thiol metabolism and antioxidant systems complement each other during arsenate detoxification in Ceratophyllum demersum L. Aquat. Toxicol. 86, 205-215.

Mishra, S., Tripathi, R.D., Srivastava, S., Dwivedi, S., Trivedi, P.K., Dhankher, O.P., Khare, A., 2009. Thiol metabolism play significant role during cadmium detoxification by Ceratophyllum demersum L. Bioresour. Technol. 100, 2155-2161.

Mishra, S., Wellenreuther, G., Mattusch, J., Stärk, H.-J., Küpper, H., 2013. Speciation and distribution of arsenic in the non-hyperaccumulator macrophyte Ceratophyllum demersum L. Plant Physiol. 163, 1396-1408.

Mishra, S., Stärk, H.-J., Küpper, H., 2014. A different sequence of events than previously reported leads to arsenic-induced damage in Ceratophyllum demersum L. Metallomics 6, 444-454.

Pätsikkä, E., Kairavuo, M., Šeršen, F., Aro, E.-M., Tyystjärvi, E., 2002. Excess copper predisposes photosystem II to photoinhibition in vivo by outcompeting iron and causing decrease in leaf chlorophyll. Plant Physiol. 129, 1359-1367.

Palms, J.M., Yanez, J., Gomez, M., del Rio, L.A., 1990. Copper-binding proteins and copper tolerance in Pisum sativum L. Plants 181, 487-495.

Peng, H., Kroneck, P.M.H., Küpper, H., 2013. Toxicity and deficiency of copper in Elsholtzia splendens affect photosynthesis biophysics pigments and metal accumulation. Environ. Sci. Technol. 47, 6120-6128.

Piug, S., 2014. Function and regulation of the plant COPT family of high-affinity copper transport proteins. Adv. Bot., http://dx.doi.org/10.1155/2014/476917.

Pospíšil, P., 2012. Molecular mechanisms of production and scavenging of reactive oxygen species by photosystem II. Biochim. Biophys. Acta 1817, 218-231.

Puig, S., Andrés-Colás, N., Garcia-Molina, A., Peñarrubia, L., 2007. Copper and iron homeostasis in Arabidopsis: response to metal deficiencies interactions and biotechnological applications. Plant Cell Environ. 30, 271-290.

Salam, Z.A., 2001. Diagnosis of copper deficiency through growth, nutrient uptake and some biochemical reactions in Pisum sativum L. Pak. J. Biol. Sci. 4, 1299-1302.

Sandmann, G., Böger, P., 1983. The enzymatological function of heavy metals and their role in electron transfer processes of plants. In: Läuchli, A., Bieleski, R.L. (Eds.), Encyclopedia of Plant Physiology. Springer-Verlag, Berlin, pp. 563-596.

Shikanai, T., Muller-Moule, P., Munekage, Y., Nyogi, K.K., Pilon, M., 2003. PAA1, a P-type ATPase of Arabidopsis, functions in copper transport in chloroplasts. Plant Cell 15, 1333-1346. 
Sommer, A.L., 1931. Copper as an essential element for plant growth. Plant Physiol. 6, 339-345

Spiller, S., Terry, N., 1980. Limiting factors in photosynthesis. Plant Physiol. 65 $121-125$

Stevenson, F.J., 1986. Cycles of Soil-Carbon, Nitrogen, Phosphorous Sulphur, Micronutrients. John Wiley \& Sons, New York, pp. 380

Taiz, L., Zeiger, E., 2007. Plant Physiology. Springer-Verlag, Berlin, Germany. Thomas, G., Stärk, H.-J., Wellenreuther, G., Dickinson, B.C., Küpper, H., 2013. Effects of nanomolar copper on water plants-Comparison of biochemical and biophysical mechanisms of deficiency and sublethal toxicity under environmentally relevant conditions. Aquat. Toxicol. 140-141, 27-36.

Vallee, B.L., Wacker, W.E.C., 1970. Metal-protein interactions. In: Neurath, H. (Ed.), The Proteins. Academic Press, New York, pp. 25-60.

Van Camp, W., Capiau, K., Van Montagu, M., Inze, D., Slooten, L., 1996. Enhancement of oxidative stress tolerance in transgenic tobacco plants overproducing Fe-superoxide dismutase in chloroplasts. Plant Physiol. 112, 1703-1714

Vaughan, D., DeKock, P.C., Ord, B.G., 1982. The nature and localisation of superoxide dismutase in fronds of Lemna gibba L. and the effect of copper and zinc defciency on its activity. Physiol. Plantarum 54, 253-257.
Yamamoto, H., Tatsuyama, K., Uchiwa, T., 1985. Fungal flora of soil polluted with copper. Soil Biol. Biochem. 17, 785-790.

Yamasaki, H., Abdel-Ghany, S.E., Cohu, C.M., Kobayashi, Y., Shikanai, T., Pilon, M., 2007. 2007: Regulation of copper homeostasis by micro-RNA in Arabidopsis. J. Biol. Chem. 282, 16369-16378.

Yu, Q., Rengel, Z., 1999. Micronutrient deficiency in plant growth and activities of superoxide dismutases in narrow-leafed lupins. Ann. Bot. 83, 175-182.

Yu, Q., Osborne, L.D., Rengel, Z., 1998. Micronutrient deficiency changes activities of superoxide dismutase and ascorbate peroxidase in tobacco plants. J. Plant Nutr. 21, 1427-1437.

Zhang, M., He, Z., Calvert, D.V., Stoffella, P.J., Yang, X., 2003. Surface runoff losses of copper and zinc in sandy soils. J. Environ. Qual. 32, 909-915.

Zhao, F., McGrath, S.P., Crosland, A.R., 1994. Comparison of three wet digestion methods for the determination of plant sulphur by inductively coupled plasma atomic emission spectrometry (ICP-AES). Commun. Soil Sci. Plant Anal. 25 407-418. 